\title{
CASEREPORT What happens after an oral ingestion of haloperidol decanoate? - A case report
}

\author{
O que ocorre após a ingestão oral de decanoato \\ de haloperidol? - Um caso clínico \\ João Perestrelo ${ }^{1}$ \\ http://orcid.org/0000-0003-0172-4863 \\ Ana Coutinho? \\ Georgina Lapa?
}

\section{Keywords}

Antipsychotic, ingestion, haloperidol decanoate, treatment, schizophrenia.

\section{Palavras-chave}

Antipsicótico, ingestão, decanoato de haloperidol, tratamento, esquizofrenia.

\begin{abstract}
Haloperidol decanoate is a first generation antipsychotic drug used to treat patients with schizophrenic disorder who require prolonged parenteral antipsychotic therapy. Cases of oral haloperidol decanoate are rare, and only one has been reported in foreign literature. In this report, we present a case of an oral ingestion of haloperidol decanoate of a male with schizophrenic disorder who presented to the emergency department following an oral ingestion of 1 ampoule of haloperidol decanoate $100 \mathrm{mg}$. At presentation he was hemodynamically stable. He was maintained on vigilance for 12 hours after what was discharged to the outpatient unit for psychiatric follow-up. The bioavailability and pharmacokinetic of oral intake of haloperidol decanoate are unknown. Although there is a report of treatment with oral activated charcoal in this case there was no need of intervention.
\end{abstract}

\section{RESUMO}

O decanoato de haloperidol é um antipsicótico de primeira geração utilizado no tratamento de pacientes com esquizofrenia que requeiram tratamento antipsicótico parentérico prolongado. Casos de intoxicação oral com decanoato de haloperidol são raros, e apenas um foi reportado na literatura estrangeira. Neste artigo apresentamos o caso de ingestão oral de decanoato de haloperidol realizada por um homem com esquizofrenia que se apresentou no serviço de urgência após a ingestão oral de uma ampola de 100 mg de decanoato de haloperidol. À apresentação, evidenciava estabilidade hemodinâmica. Foi mantido em vigilância durante 12 horas, após as quais teve alta e foi orientado a realizar consulta externa com psiquiatria para seguimento. A biodisponibilidade e a farmacocinética da ingestão oral de decanoato de haloperidol sãp desconhecidas. Apesar de estar descrito o tratamento oral com carvão ativado, neste caso não houve necessidade de intervenção.

1 Centro Hospitalar Vila Nova de Gaia/Espinho, Porto, Portugal.



DOI: 10.1590/0047-2085000000225

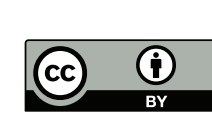

Address for correspondence: João Perestrelo

Rua Conceição Fernandes, s/n

Vila Nova de Gaia

4400-129 - Porto, Portugal

E-mail: joaomfp@hotmail.com 


\section{INTRODUCTION}

Haloperidol decanoate is the decanoate ester of haloperidol. It is an effective typical antipsychotic drug approved to treat patients with schizophrenic disorder who require prolonged parenteral antipsychotic therapy'. The basic effects of haloperidol decanoate are the same as those of oral haloperidol, with the exception of duration of action.

Haloperidol is a typical butyrophenone type antipsychotic. Its antipsychotic actions are thought to be mediated by dopaminergic D2 receptors inhibition' 1 . The drug also interacts with histamine, muscarinic, adrenergic receptors and delayed rectifier potassium channel${ }^{2}$. Administration of haloperidol decanoate as a depot intramuscular injection results in a slow and sustained release of haloperidol. It is administered in 2- to 4-weeks intervals as maintenance therapy ${ }^{3}$. Its adverse effects include QTC prolongation, torsade de points, neuropletic malignant syndrome, extrapyramidal symptoms, and seizures, among others'. The effects of oral intake of haloperidol decanoate are unknown. This case report describes an acute ingestion of $100 \mathrm{mg}$ of haloperidol decanoate.

\section{CASE REPORT}

A 52 years-old man, diagnosed with schizophrenic disorder, presented at the emergency room 6 hours after intentionally ingesting one ampoule of haloperidol decanoate 100 mg. This happened following a family conflict that provoked great distress on him. He had been treated with haloperidol decanoate intramuscularly in a 4 weeks schedule for 10 years and the last dose was administrated 3 weeks before the event. He was also on biperiden $4 \mathrm{mg} /$ day (prolonged release). When admitted, he was hemodynamically stable with a Glasgow coma score of 15, a body temperature of 36.3 Celsius degrees, a blood pressure of $127 / 71 \mathrm{mmHg}$, a heart rate of 63 beats/min and a respiratory rate of 14 breaths/min, with an oxygen saturation of $98 \%$ on room air. The laboratory tests and the electrocardiogram where within reference range. He was maintained on vigilance for 12 hours showing no signs of hemodynamic instability. After this period the patient was observed by the emergency psychiatric team. At the time of examination, he presented himself with a careless aspect, looking older than his real age. No signs of tremor or abnormal movements were detected. He was cooperative throughout the interview, maintaining eye contact. His speech was clearly articulated, spontaneous, at a normal rate and speed. His mood was neutral, with blunted affect. His thought had no changes in stream or form, and there were no signs of delusional ideas or hallucinatory activity. Suicidal ideation was not detected and the patient revealed regretted about the ingestion. After that he was transferred to the outpatient unit for psychiatric follow-up.

\section{DISCUSSION}

Currently, there is almost none information in the literature about the clinical course of an oral ingestion of haloperidol decanoate. In the current case the effects were mild, but symptoms of intoxication with haloperidol can include adverse reactions such as extrapyramidal, cardiac (QT interval prolongation) and anticholinergic effects ${ }^{2,4-6}$. Fatalities after intoxications with high doses of haloperidol have been described, which imposes a great risk of developing neuroleptic malignant syndrome?.

After intramuscular injection, haloperidol decanoate is gradually released to the circulation, then the ester is hydrolysed by endogenous esterases to haloperidol ${ }^{8}$. The bioavailability and pharmacokinetic of oral intake of haloperidol decanoateare unknown; however theesterislikely to be hydrolysed to haloperidol by the acidic environment in the stomach or by digestive enzymes in the small intestine? This implies that the complete dose of haloperidol could be released which turns this intoxication in a life threatening situation. In this case, the patient stood in active vigilance but another report defends that oral activated charcoal should be administered as soon as possible to capture and eliminate haloperidol and haloperidol decanoate². Blood levels of haloperidol, if available, should also be monitored ${ }^{9}$. Based on this, we cannot recommend a specific approach as, in this case, the patient remain stable without any intervention. Maybe, for precaution, these patients could be treated with oral activated charcoal but there is not enough evidence for this recommendation. The observation and permanence, for at least 12 hours, in the emergency department or intensive care unit should be offered to all patients until any kind of symptoms have resolved.

\section{CONCLUSION}

Adverse and life threatening reactions can occur after oral ingestion of haloperidol decanoate, associated with the mechanism of action of the active drug, haloperidol. However, the biopharmaceutical effects of such route of intake are unknown. In this case there was no need for intervention besides active vigilance in the emergency unit.

\section{INDIVIDUAL CONTRIBUTIONS}

João Perestrelo - Conception and design of the article. Ana Coutinho - Design and critical revision of the article content.

Georgina Lapa - Critical review and final approval for publication. 


\section{CONFLICTS OF INTEREST}

No author has a conflict of interest.

\section{REFERENCES}

1. Stahl SM. Essential Psychopharmacology Online. 2008. Available at: https://stahlonline. cambridge.org/prescribers_drug.jsf?page $=9781316618134$ c55.html.therapeutics\&nam eHaloperidol\&title=Therapeutics. Accessed on: October 27, 2017.

2. Dekkers BGJ, Eck RJ, Ter Maaten JC, Touw DJ. An acute oral intoxication with haloperidol decanoate. Am J Emerg Med. 2017;35(9).

3. Infarmed. Decanoate Haloperidol. [online]. 2017. Available at: http://app7.infarmed.pt/ infomed/download_ficheiro.php?med_id=4122\&tipo_doc=fi. Accessed on: 0 ctober 27, 2017.
4. Baselt RC. Biomedical Publications. 2014.

5. Scialli JV, Thornton WE. Toxic reactions from a haloperidol overdose in two children. Thermal and cardiac manifestations. JAMA. 1978;239(1):48-9.

6. Volavka J, Cooper T, Czobor P, Bitter I, Meisner M, Laska E, et al. Haloperidol blood levels and clinical effects. Arch Gen Psychiatry. 1992;49(5):354-61.

7. Levine BS, Wu SC, Goldberger BA, Caplan YH. Two fatalities involving haloperidol. J Anal Toxicol. 1991;15(5):282-4.

8. Deberdt R, Elens P, Berghmans W, Heykants J, Woestenborghs R, Driesens F, et al. Intramuscular haloperidol decanoate for neuroleptic maintenance therapy. Efficacy, dosage schedule and plasma levels. An open multicenter study. Acta Psychiatr Scand. 1980;62:356-63.

9. Ulrich S, Wurthmann C, Brosz M, Meyer FP. The relationship between serum concentration and therapeutic effect of haloperidol in patients with acute schizophrenia. Clin Pharmacokinet. 1998;34(4):227-63. 